\title{
Studies on the Antagonism by Chloramphenicol of Carbon Tetrachloride-Induced Damage: Examination of Mitochondrial Protein Synthesis 1
}

\author{
Michael J. Brabec, Craig Bradley, and I. A. Bernstein \\ Environmental Cellular Chemistry Laboratory and Department of Biological Chemistry, The University \\ of Michigan, Ann Arbor, Michigan 48109
}

Received April 2, 1976; accepted June 10, 1976

\begin{abstract}
Studies on the Antagonism by Chloramphenicol of Carbon Tetrachloride-Induced Damage: Examination of Mitochondrial Protein Synthesis. Brabec, M. J., Bradley, C., AND Bernstein, I. A. (1976). Toxicol. Appl. Pharmacol. 38, 157-167. The damage induced in the mitochondria of rat liver during intoxication by carbon tetrachloride is prevented by the administration of chloramphenicol early in the intoxication. The possibility that the protective ability of chloramphenicol lies in the compound's ability to inhibit mitochondrial protein synthesis was eliminated by the failure of other inhibitors of mitochondrial protein synthesis, namely Tevenel, a chloramphenicol analog, and oxytetracycline, to prevent mitochondrial damage. Conversely, the optical isomer of chloramphenicol, which is not an inhibitor of mitochondrial protein synthesis, and does not possess antibiotic activity, does prevent mitochondrial damage during intoxication by $\mathrm{CCl}_{4}$. SKF $525 \mathrm{~A}$ also preserves mitochondrial integrity, albeit not as well as chloramphenicol. Chloramphenicol, early in the course of intoxication, partially prevents the characteristic loss of protein synthesis after $\mathrm{CCl}_{4}$. It was concluded that the protective action of chloramphenicol could be due to either an interdiction of a destructive event triggered by $\mathrm{CCl}_{4}$, or to the preservation of the cellular repair processes being scrved by protein synthesis in the cytosol.
\end{abstract}

The hepatotoxic effects of $\mathrm{CCl}_{4}$ that lead to hepatic necrosis in the rat involve, at least in part, a loss of mitochondrial function (Reynolds et al., 1962). Restoration of mitochondrial function seems concomitant with animal recovery and involves repair of damaged mitochondrial elements (Brabec et al., 1974). During the study of these repair processes in the $\mathrm{CCl}_{4}$-damaged rat liver, chloramphenicol was found to be a potent antagonist of the $\mathrm{CCl}_{4}$-induced mitochondrial lesion, and to ameliorate the hepatotoxicity of $\mathrm{CCl}_{4}$ in general ${ }^{2}$ (Brabec and Bernstein, 1975). Similar observations have since been reported by Huyen and Banaschak (1973).

\footnotetext{
${ }^{1}$ This investigation was supported by Public Health Grant No. R01-ES01024 from the National Institute of Environmental Health Sciences.

${ }^{2}$ Brabec, M. J., and Bernstein, I. A. " "Recovery of Liver Mitochondria following $\mathrm{CCl}_{4}$ Exposure," presented to the Biochemistry Section, American Chemical Society, Washington, D.C., September, 1971.
}

Copyright $\bigcirc 1976$ by Academic Press, Inc. 
The etiology of $\mathrm{CCl}_{4}$-intoxication and the known metabolic effects of chloramphenicol suggest the following possible loci for protection by chloramphenicol. (a) Mitochondrial protein synthesis: Chloramphenicol inhibits mitochondrial protein synthesis, and is reported to bind to the acceptor site of the $50 \mathrm{~S}$ ribosomal subunit (Contreras et al., 1974). A novel possibility is that the biosynthetic operations of the mitochondrion in the $\mathrm{CCl}_{4}$-traumatized hepatocyte are impaired and mitochondrial dysfunction results from the accumulation of protein(s). Chloramphenicol would prevent such an accumulation, and thereby the incipient mitochondrial lesion. Such a mechanism has been offered to explain the protection cycloheximide offers cells of the intestinal crypt after X-irradiation (Lieberman et al., 1970). (b) $\mathrm{CCl}_{4}$ metabolism: The initial molecular lesion induced by $\mathrm{CCl}_{4}$ is thought to be the result of the production of an activated metabolite of $\mathrm{CCl}_{4}$ by microsomal enzymes. The activated metabolite is postulated to bind to an adjacent membrane molecule, disrupting function (Reynolds, 1972), or to initiate a homolytic lipid peroxidation of the unsaturated fatty acids of the phospholipids in the membrane (Recknagel et al., 1974). Chloramphenicol has been reported to be an inhibitor of the $N$-dealkylation of aminopyrine in vitro (Dixon and Fouts, 1962) and to prolong the sleeping time of hexobarbital-exposed rats (Grogan $e t$ al., 1972). Chloramphenicol decreases the formation of $\mathrm{CHCl}_{3}$ from $\mathrm{CCl}_{4}$ in rats (Huyen and Banaschak, 1973). The theory that toxicity results from the metabolism of $\mathrm{CCl}_{4}$ would predict a protective action by chloramphenicol due to inhibition of $\mathrm{CCl}_{4}$ metabolism. The purpose of this study was to elucidate the antagonism of $\mathrm{CCl}_{4}$-intoxication by chloramphenicol.

\section{METHODS}

White laboratory rats, $\mathrm{CFN}$ strain, weighing $180-250 \mathrm{~g}$, were used. $\mathrm{CCl}_{4}$ was injected ip, without carrier, at $1.2 \mathrm{ml} / \mathrm{kg}$, a dose that permitted $80 \%$ of the animals to survive the intoxication. The sodium succinyl salt of chloramphenicol and SKF $525 \mathrm{~A}^{3}$ were dissolved in distilled water, $100 \mathrm{mg} / \mathrm{kg}$, and given ip at the indicated dose regimen. Typically, the animals received $\mathrm{CCl}_{4}$ followed immediately by $100 \mathrm{mg} / \mathrm{kg}$ of chloramphenicol, and were sacrificed $40 \mathrm{hr}$ later. D-CAP, L-CAP (the respective optical isomers of threo-chloramphenicol) and Tevenel (a sulfamoyl analog of chloramphenicol) were dissolved, $50 \mathrm{mg} / \mathrm{ml}$, in propylene glycol and administered ip at selected doses as indicated. Oxytetracycline dissolved in propylene glycol, $50 \mathrm{mg} / \mathrm{ml}$, was also injected ip $^{4}$.

Mitochondria, prepared from rat livers, were assayed polarographically in an YSI Model 53 Biological Oxygen Monitor as previously described (Brabec et al., 1974). The respiratory control ratio was calculated from the State 3 (+ADP) and State 4 (-ADP) oxygen uptake rates as described by Estabrook (1967). Mitochondrial protein was determined by the Biuret method (Jacobs et al., 1956).

${ }^{3}$ The abbreviations used are: D-CAPS, D-threo-chloramphenicol, succinyl sodium salt; D-CAP, L-CAP, the respective optical isomers of threo-chloramphenicol; SKF 525A, $\beta$-diethylaminoethyl2,3-diphenylpropyl acetate; ADP, adenosine diphosphate; TCA, trichloroacetic acid; RCR, respiratory control ratio.

${ }^{4}$ D-CAPS, D-CAP, and L-CAP were generously provided by Dr. Stanley Kurtz, Parke-Davis Co., Ann Arbor, Mich. Tevenel was donated by Dr. C. E. Hoffman, du Pont de Nemours and Co., Wilmington, Del. Oxytetracycline (Liquamycin) was obtained from Chas. Pfizer Co. 
Incorporation of amino acids was determined in animals injected ip with $50 \mu \mathrm{Ci}$ per $200 \mathrm{~g}$ body weight $\left[3,4-{ }^{3} \mathrm{H}\right]$ leucine (sp act $60 \mathrm{Ci} / \mathrm{mmol}$ ) either 4.5 or $25.5 \mathrm{hr}$ after $\mathrm{CCl}_{4}$ administration ( 30 min prior to sacrifice). The mitochondria were prepared, and acidinsoluble radioactivity was determined by a modification of the method of Mans and Novelli (1961). The mitochondrial suspension was diluted with $0.05 \mathrm{M}$ L-leucine to a concentration of $10 \mathrm{mg} / \mathrm{ml}$ and sonicated $1 \mathrm{~min}$ at $8 \mathrm{~A}$ on a Bronson Sonifier, Model LS-75. Approximately $0.8 \mathrm{mg}$ of mitochondrial protein was streaked on $1-\times 6-\mathrm{cm}$ strips of Whatman \#1 filter paper and immediately submerged in ice-cold $10 \%$ TCA$0.025 \mathrm{M} \mathrm{L}$-leucine for $30 \mathrm{~min}$. The strips were then successively transfered at $15-\mathrm{min}$ intervals through the following solutions at the indicated temperatures $\left(\mathrm{C}^{\circ}\right): 10 \%$ TCA, $0^{\circ} ; 10 \% \mathrm{TCA}, 90^{\circ} ; 5 \% \mathrm{TCA}, 0^{\circ}$; ethanol-ether, $20^{\circ}$. The strips were then dryed in an oven, placed in $8 \mathrm{ml}$ of a scintillation cocktail (Packard Permablend I), and counted in a Packard Tri-Carb liquid scintillation counter. Net counts per minute were recorded. Controls, which had received $100 \mathrm{mg} / \mathrm{kg}$ of D-CAPS 4.5 or $26.5 \mathrm{hr}$ prior to $\left[3,4-{ }^{3} \mathrm{H}\right]$ leucine, were not significantly different from nonintoxicated controls in incorporation rates.

Incorporation of amino acids into acid-insoluble protein by isolated mitochondria was determined by the procedure of Simpson et al. (1967), as described previously (Brabec et al., 1974). Mitochondria were prepared aseptically from animals which had becn pretreated with D-CAPS or oxytetracycline at selected doses and times. After incubation with $\left[\mathrm{U}-{ }^{14} \mathrm{C}\right]$ leucine (sp act $326 \mathrm{Ci} / \mathrm{mol}$ ), the mitochondrial suspension was washed free of soluble $\left[{ }^{14} \mathrm{C}\right]$ leucine and the acid-insoluble radioactivity was determined as described above. Bacterial contamination, monitored by streaking an aliquot of the incubation mixture on nutrient agar plates and incubating for $24 \mathrm{hr}$ at $37^{\circ} \mathrm{C}$ was always less than 500 colonies/ml of incubation mixture.

Statistical analysis. The ability of a selected drug to prevent mitochondrial damage suffered during exposure to $\mathrm{CCl}_{4}$ was evaluated by use of the Student's $t$ test (Schefler, 1969).

\section{RESULTS}

The respiratory control ratio ( $R C R$ ) was monitored as an indicator of mitochondrial integrity. The appearance of mitochondrial damage was marked by a decline of the RCR, due to an increase in the State 4 (-ADP) rate, and a decrease in the State 3(+ADP) rate, as is shown in Fig. 1. Since maximum damage was noted at $40 \mathrm{hr}$ after administration of $\mathrm{CCl}_{4}$, and recovery in the RCR values began at $40-50 \mathrm{hr}$, mitochondria for these studies were prepared from rats after $36-40 \mathrm{hr}$ of intoxication. The RCR values for animals similarly treated with $\mathrm{CCl}_{4}$, but having received $100 \mathrm{mg} / \mathrm{kg}$ of D-CAPS at 0 time, are also displayed in Fig. 1. Only a slight decline in the RCR was noted. Mortality of the experimental animals provides another estimation of protection. During these experiments, $72 \%$ of the intoxicated animals ( 53 of 73 experimental animals) and $98 \%$ of the protected animals ( 59 of 60 ) survived at least $40 \mathrm{hr}$.

Protection by D-CAPS as a function of dosage is shown in Fig. 2. Below $50 \mathrm{mg} / \mathrm{kg}$ protection declined rapidly, with slight protection offered by $25 \mathrm{mg} / \mathrm{kg}$ D-CAPS. Since mitochondrial dysfunction is a late development during $\mathrm{CCl}_{4}$ intoxication (RCR values are normal for the first $10 \mathrm{hr}$ after $\mathrm{CCl}_{4}$ exposure), the ability of D-CAPS to 
protect as a function of time after the administration of $\mathrm{CCl}_{4}$ is critical to the consideration of possible protective mechanisms. As seen in Fig. 3, for any protection, D-CAPS had to be delivered to the intoxicated rat within $7 \mathrm{hr}$ after the animal had received the $\mathrm{CCl}_{4}$.

A system was devised to determine whether the inhibition of mitochondrial protein synthesis was a possible mechanism for protection. If inhibition of mitochondrial protein synthesis were the mechanism by which D-CAP prevents mitochondrial damage

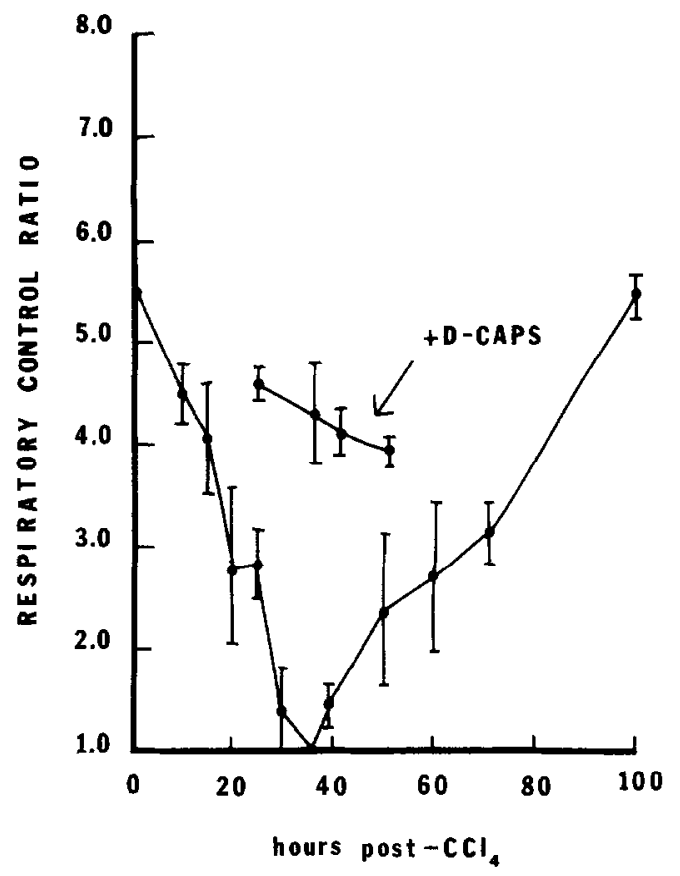

FIG. 1. The course of the hepatic mitochondrial lesion during $\mathrm{CCl}_{4}$ intoxication, in the presence ( $+\mathrm{D}-\mathrm{CAPS}$ ) and absence of $100 \mathrm{mg} / \mathrm{kg} \mathrm{D}-\mathrm{CAPS}$ at 0 time. The parameter of mitochondrial integrity displayed is the ratio of the ADP-stimulated to ADP-absent oxidation rate (RCR, respiratory control ratio). Each point represents the mean $\pm S E$ of at least seven animals.

during $\mathrm{CCl}_{4}$ intoxication, the model would predict that other inhibitors of mitochondrial protein synthesis would be effective protective agents. The effects of the sulfamoyl derivative of chloramphenicol, Tevenel, which is an antibiotic and an inhibitor of mitochondrial protein synthesis; the optical isomer of chloramphenicol, L-CAP, which is inactive as an antibiotic or as an inhibitor of mitochondrial protein synthesis (Fettes et al., 1972); and oxytetracycline, which is an inhibitor of mitochondrial protein synthesis (DeVries and Kroon, 1970); are compared with the predictions of the model in Table 1. Neither oxytetracycline nor Tevenel would significantly prevent the decline of $\mathrm{RCR}$ caused by $\mathrm{CCl}_{4}$. L-CAP, on the other hand, did protect. It is also interesting to note that the effects of L-CAP and D-CAP were not significantly different from each other, but were inferior to the water-soluble monosuccinate derivative of chloramphenicol, D-CAPS. 


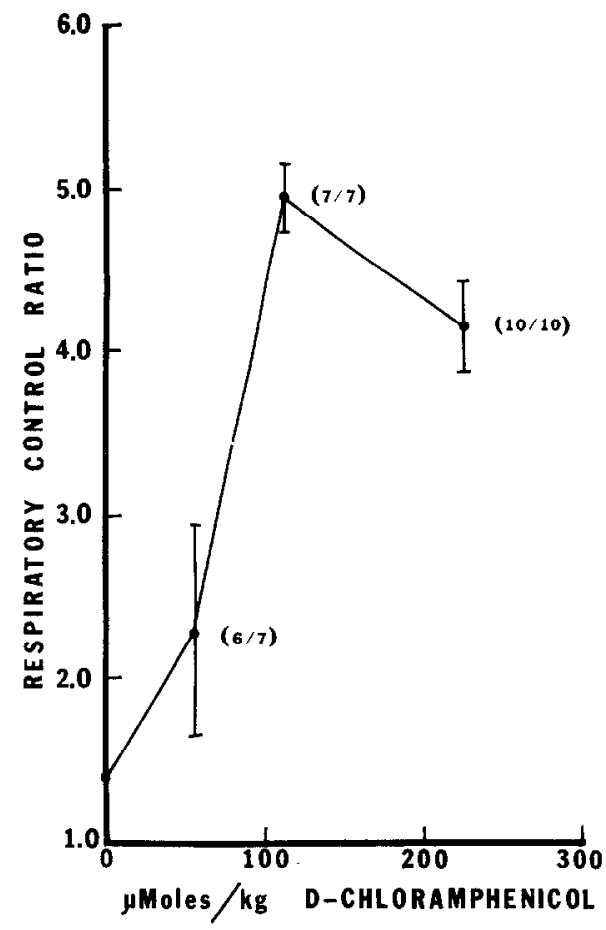

FIG. 2. The effectiveness of D-CAPS as a mitochondrial protective agent as a function of dose. Mitochondria were isolated from animals $40 \mathrm{hr}$ after $\mathrm{CCl}_{4}$ injection. D-CAPS was injected simultaneously with $\mathrm{CCl}_{4}$ at 0 time. The numbers in parentheses represent the survival/treated at each time point; each point represents the mean $\pm S F$. Control RCR $=5.1$.

TABLE 1

The Mitochondrial Protective Capabilities of Mitochondrial and Microsomal INHIBITORS DURING $\mathrm{CCl}_{4}$ INTOXICATION $^{a}$

\begin{tabular}{ll}
\hline \multicolumn{1}{c}{ Treatment } & RCR $\pm \mathrm{SD}$ \\
\hline Control & $5.10 \pm 0.84(11)$ \\
$\mathrm{CCl}_{4}(1.2 \mathrm{ml} / \mathrm{kg})$ & $1.34 \pm 0.46(20)$ \\
+D-chloramphenicol, succinyl salt $(100 \mathrm{mg} / \mathrm{kg})$ & $4.11 \pm 0.66(10)$ \\
+D-chloramphenicol $(100 \mathrm{mg} / \mathrm{kg})$ & $3.27 \pm 0.47(7)^{c}$ \\
+L-chloramphenicol $(100 \mathrm{mg} / \mathrm{kg})$ & $2.60 \pm 1.15(7)^{c}$ \\
+Tevenel $(50 \mathrm{mg} / \mathrm{kg})$ & $1.50 \pm 0.83(5)^{b}$ \\
+Tevenel $(100 \mathrm{mg} / \mathrm{kg})$ & $1.49 \pm 0.22(7)^{b}$ \\
+Oxytetracycline $(50 \mathrm{mg} / \mathrm{kg})$ & $2.01 \pm 1.14(5)^{b}$ \\
+SKF 525A (0 time, $100 \mathrm{mg} / \mathrm{kg})$ & $2.58 \pm 1.03(4)$ \\
+SKF 525A (30 min prior to CCl $\left.{ }_{4}, 40 \mathrm{mg} / \mathrm{kg}\right)$ & $2.91 \pm 1.34(7)$ \\
\hline
\end{tabular}

a $\mathrm{CCl}_{4}$-intoxicated rats were injected with the selected drug as described in Methods. Liver mitochondria were prepared after $40 \mathrm{hr}$ of intoxication and the respiratory control ratio (RCR) was determined. Numbers in parentheses indicate numbers of animals used for each determination. D-CAPS, D-CAP, L-CAP, and SKF 525A offered protection, drug-treated vs $\mathrm{CCl}_{4}(p<0.001)$.

${ }^{b}$ Not significant, drug-treated vs $\mathrm{CCl}_{4}(p<0.1)$.

c Not significant, L-chloramphenicol vs D-chloramphenicol $(p<0.1)$. 
To further evaluate the inhibition of mitochondrial protein synthesis as a protective mechanism, the relative effectiveness of D-CAPS and oxytetracycline as inhibitors of mitochondrial protein synthesis in vitro was determined. Mitochondria were isolated and assayed for amino acid incorporation rates at selected periods following injection of either D-CAPS or oxytetracycline. As seen in Table 2, oxytetracycline was a more potent and persistent inhibitor of mitochondrial protein synthesis than was D-CAPS

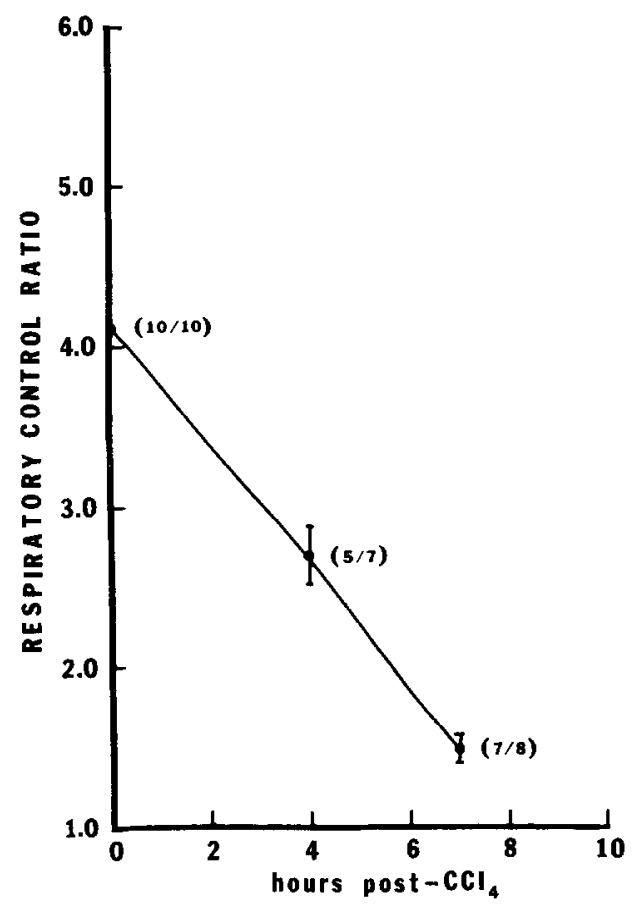

FIG. 3. The effectiveness of D-CAPS as a mitochondrial protective agent as a function of time of delivery after $\mathrm{CCl}_{4}$. Methods as in Fig. 2. Mitochondria were isolated and assayed $40 \mathrm{hr}$ after $\mathrm{CCl}_{4}$. D-CAPS $(100 \mathrm{mg} / \mathrm{kg})$ was given at the indicated times after $\mathrm{CCl}_{4}$. Each point represents the mean $\pm \mathrm{SE}$.

although neither antibiotic achieved complete inhibition for a prolonged period of time.

The failure of oxytetracycline and Tevenel, and the success of L-CAP in preserving mitochondrial activity during $\mathrm{CCl}_{4}$ intoxication, suggest that the protective abilities of chloramphenicol are being expressed at some point in the cell other than the mitochondrial ribosome. The reports of the inhibition of the microsomal drug metabolizing system by chloramphenicol (Dixon and Fouts, 1962) and the involvement of the microsomal enzymes in intoxication by $\mathrm{CCl}_{4}$ (Recknagel et al., 1974) point to the endoplasmic reticulum as a possible site of the protective action of the antibiotic. To examine this possibility, the protective abilities of chloramphenicol were compared with those of SKF 525A, a known antagonist of $\mathrm{CCl}_{4}$ intoxication (Cignoli and Castro, 1971; Reynolds and Moslen, 1974). SKF 525A is a potent inhibitor of microsomal enzyme activity, a mechanism offered to explain its antagonism to intoxication from $\mathrm{CCl}_{4}$. 
TABLE 2

In Vitro Amino Acid Incorporation by Isolated Mitochondria Following In Vivo EXPOSURE TO D-CAPS OR OXYTETRACYCLINE ${ }^{a}$

\begin{tabular}{|c|c|c|c|}
\hline \multirow[b]{2}{*}{ Treatment } & \multirow[b]{2}{*}{ Exposure period } & \multicolumn{2}{|c|}{$\begin{array}{l}{\left[\mathrm{U}-{ }^{14} \text { C]leucine }\right.} \\
\text { incorporation }\end{array}$} \\
\hline & & $\mathrm{cpm} / \mathrm{mg} / \mathrm{hr}$ & $\%$ Control \\
\hline \multicolumn{4}{|c|}{ D-chloramphenicol, succinyl salt } \\
\hline $25 \mathrm{mg} / \mathrm{kg}$ & $30 \mathrm{~min}$ & $\begin{array}{l}1288 \\
1040\end{array}$ & 124 \\
\hline $100 \mathrm{mg} / \mathrm{kg}$ & $30 \mathrm{~min}$ & $\begin{array}{r}978 \\
1316\end{array}$ & 74 \\
\hline $100 \mathrm{mg} / \mathrm{kg}$ & $60 \mathrm{~min}$ & $\begin{array}{r}87^{b} \\
184^{b}\end{array}$ & 51 \\
\hline $300 \mathrm{mg} / \mathrm{kg}$ & $60 \mathrm{~min}$ & $\begin{array}{l}293^{b} \\
480^{b}\end{array}$ & 61 \\
\hline $\begin{array}{l}\text { Oxytetracycline } \\
50 \mathrm{mg} / \mathrm{kg} \\
\text { Propylene glycol }\end{array}$ & $30 \mathrm{~min}$ & $\begin{array}{r}432 \\
1040\end{array}$ & 42 \\
\hline $\begin{array}{l}100 \mathrm{mg} / \mathrm{kg} \\
\text { Propylene glycol } \\
100 \mathrm{mg} / \mathrm{kg}\end{array}$ & $\begin{array}{l}30 \mathrm{~min} \\
8 \mathrm{hr}\end{array}$ & $\begin{array}{r}419 \\
820 \\
1210\end{array}$ & 51 \\
\hline Propylene glycol & & 1360 & \\
\hline
\end{tabular}

${ }^{a}$ Rats were injected with the indicated inhibitor or, in the case of oxytetracycline controls, an equal volume of propylene glycol. Hepatic mitochondria were aseptically prepared at selected times later, and incubated with $\left[\mathrm{U}-{ }^{14} \mathrm{C}\right]$ leucine. The incorporation of radioactivity into acid-insoluble protein was measured.

${ }^{b}$ These experiments contained $0.5 \mu \mathrm{Ci} /$ reaction; all others contained $1 \mu \mathrm{Ci} /$ reaction.

As may be seen in Table 1, SKF 525A provided a low level of protection for mitochondria during $\mathrm{CCl}_{4}$ intoxication. However, if delivery of SKF 525A occurred $30 \mathrm{~min}$ prior to the administration of $\mathrm{CCl}_{4}$, protection was much more obvious.

The similarity in the antagonism to $\mathrm{CCl}_{4}$ intoxication provided by SKF-525A and D-CAPS suggests that D-CAPS may be exerting its action on the microsomal enzymes responsible for activation of $\mathrm{CCl}_{4}$. A characteristic membrane lesion of $\mathrm{CCl}_{4}$ intoxication is the degranulation of the rough endoplasmic reticulum, and the concomitant inhibition of protein synthesis (Smuckler et al., 1962; Reynolds and Ree, 1971). The inhibition is transient, however, and normal rates of synthesis are achieved $20 \mathrm{hr}$ after exposure to $\mathrm{CCl}_{4}$. The effect of D-CAPS on this aspect of $\mathrm{CCl}_{4}$ intoxication was examined by monitoring the incorporation of $\left[3,4-{ }^{3} \mathrm{H}\right]$ leucine into mitochondrial protein in vivo. As seen in Table $3, \mathrm{CCl}_{4}$ results in $55 \%$ inhibition of the incorporation of $\left[3,4-{ }^{3} \mathrm{H}\right]$ leucine into mitochondrial protein $5 \mathrm{hr}$ after administration of $\mathrm{CCl}_{4}$. D-CAPS ameliorates this inhibition, allowing only a $30 \%$ depression. However, when the incorporation of amino acid was examined at a later period $(26 \mathrm{hr})$, animals protected by D-CAPS were incorporating significantly greater amounts of $\left[3,4-{ }^{3} \mathrm{H}\right]$ leucine than were control or $\mathrm{CCl}_{4}$-intoxicated animals. 
TABLE 3

The EfFect of D-CAPS on the Inhibition of Protein Synthesis DURING CCl $_{4}$-IntoxicATion ${ }^{a}$

\begin{tabular}{|c|c|c|c|c|}
\hline \multirow[b]{4}{*}{ Animal group } & \multicolumn{4}{|c|}{ Specific activity of mitochondrial protein } \\
\hline & \multicolumn{4}{|c|}{ Time post- $\mathrm{CCl}_{4}$} \\
\hline & \multicolumn{2}{|c|}{$5 \mathrm{hr}$} & \multicolumn{2}{|c|}{$26 \mathrm{hr}$} \\
\hline & $\mathrm{cpm} / \mathrm{mg} \pm \mathrm{SE}$ & $\begin{array}{c}\text { Control } \\
(\%)\end{array}$ & $\mathrm{cpm} / \mathrm{mg} \pm \mathrm{SE}$ & $\begin{array}{c}\text { Control } \\
(\%)\end{array}$ \\
\hline Control (2) & $264 \pm 11$ & 100 & $108 \pm 4$ & 100 \\
\hline $\mathrm{CCl}_{4}(3)$ & $118 \pm 8$ & $45^{b}$ & $181 \pm 41$ & 167 \\
\hline $\mathrm{CCl}_{4}+\mathrm{D}-\mathrm{CAPS}(3)$ & $181 \pm 17$ & $69^{c}$ & $252 \pm 17$ & $223^{b}$ \\
\hline
\end{tabular}

\footnotetext{
${ }^{a}$ Chloramphenicol was injected, $100 \mathrm{mg} / \mathrm{kg}$, to rat at the same time as $\mathrm{CCl}_{4}$. Thirty minutes prior to sacrifice, the animals were injected ip with $\left[3,4-{ }^{3} \mathrm{H}\right]$ leucine. The mitochondria were prepared and the $\left[3,4{ }^{3} \mathrm{H}\right]$ leucine incorporation into acid-insoluble protein was determined. The specific activity is expressed as counts per minute (cpm) per mg protein $\pm \mathrm{SE}$. The 5 -hr experiment used $100 \mu \mathrm{Ci} / 200 \mathrm{~g}$ of $\left[3,4-{ }^{3} \mathrm{H}\right]$ leucine per animal; the $26-\mathrm{hr}$ used $200 \mu \mathrm{Ci} / 200 \mathrm{~g}$.

${ }^{b} p<0.01$, Student's $t$ test, test vs control.

${ }^{c} p<0.05$, Student's $t$ test, test vs control.
}

\section{DISCUSSION}

Chloramphenicol is a potent antagonist of the $\mathrm{CCl}_{4}$-induced mitochondrial lesion, assuring nearly normal mitochondrial activity during a period of serious disruptive events in the cell. A number of studies relating to antagonism of intoxication by $\mathrm{CCl}_{4}$ have been published (Cignoli and Castro, 1971; Dianzani and Ugazio, 1973; Reynolds and Moslen, 1974; Slater and Sawyer, 1969), including observations that low doses of $\mathrm{CCl}_{4}$, prior to a toxic dose, act in a protective manner (Dambrauskas and Cornish, 1970; Glende, 1972). The efficacy of the protective action has been evaluated by morphological, histochemical, and biochemical criteria relating to early events of toxicity, or by increase in the LD50 of $\mathrm{CCl}_{4}$. Monitoring mitochondrial integrity has not heretofore been a parameter used in evaluating hepatic protective agents, perhaps because the mitochondrial lesion appears late during $\mathrm{CCl}_{4}$ intoxication and therefore is temporally, and spatially, removed from the initial events of intoxication. However, mitochondrial integrity is a convenient and definitive criterion of protection. Mitochondria begin to show loss of function $12-15 \mathrm{hr}$ after the administration of $\mathrm{CCl}_{4}$. The dysfunction intensifies, then disappears coincident with recovery of liver function (Reynolds et al., 1962). Therefore, the prevention of mitochondrial damage is relevant to survival of the hepatocyte.

D-CAPS has at least two major sites of interaction in the cell (the mitochondria and the endoplasmic reticulum) and both must be considered in a study of its protective action. The failure of Tevenel and oxytetracycline (inhibitors of mitochondrial protein synthesis), and the ability of L-CAP (inactive as an inhibitor of mitochondrial protein synthesis) to prevent the mitochondrial lesion (Table 1), rule against a mechanism of protection (or damage) involving mitochondrial protein synthesis. 
On the other hand, involvement of the endoplasmic reticulum is indicated. Figure 2 shows that the protection declines with time after injection of $\mathrm{CCl}_{4}$, and is absent by 7 $\mathrm{hr}$, a period that corresponds quite well with the retention of $\mathrm{CCl}_{4}$ in the tissue (Reynolds and Ree, 1971). D-CAPS is reported to increase the hexobarbital-sleeping time of rats and to inhibit the $N$-dealkylation of aminopyrine (Dixon and Fouts, 1962). However, comparison of D-CAPS with SKF 525A, a potent and persistent inhibitor of microsomal drug-metabolizing enzymes, indicates that D-CAPS is a superior protective agent. SKF 525A has been reported by several authors to be one of the most effective inhibitors of early microsomal changes during $\mathrm{CCl}_{4}$ intoxication (Cignoli and Castro, 1971; Reynolds and Moslen, 1974). As shown in Table 1, delivery of $\mathrm{CCl}_{4}$ must be delayed 30 min past the time when $\mathrm{SKF} 525 \mathrm{~A}$ is administered. Since in our studies $\mathrm{CCl}_{4}$ is delivered $\mathrm{ip}$, the inhibition of the absorption of $\mathrm{CCl}_{4}$ from the intestine by SKF 525A, as suggested by Marchand et al. (1971), would not be a likely mechanism for protection.

Studies of the antagonism of $\mathrm{CCl}_{4}$-induced alterations of the endoplasmic reticulum present a complicated picture. The relationship between biochemical and physiological disturbances in these membranes (e.g., the loss of glucose-6-phosphatase and cytochrome P-450, conjugated dienes in microsomal lipids) and the subsequent cellular pathologies (lipid infiltration, mitochondrial damage, calcium influx) is not clear. If $\mathrm{CCl}_{4}$ is metabolized by a cytochrome P-450-requiring enzyme, D-CAPS may inhibit that enzyme system. Cignoli and Castro (1971) could correlate inhibitors of drug metabolism with antagonism to $\mathrm{CCl}_{4}$ toxicity, but noted that exceptions existed. Similarly, destruction of cytochrome $\mathrm{P}-450$ by pretreatment with small doses of $\mathrm{CCl}_{4}$ markedly increased the LD50 of a subsequent toxic dose. Interestingly, the only microsomal parameter significantly altered in the pretreated animals was a decline in conjugated dienes (Recknagel et al., 1974). Despite the simplicity of the postulate that D-CAPS interrupts $\mathrm{CCl}_{4}$ metabolism, other explanations can be considered to accommodate existing data. In this regard, the conclusion that D-CAPS prevents mitochondrial damage could be erroneous. Table 3 shows that D-CAPS ameliorates, but does not abolish, the $\mathrm{CCl}_{4}$-induced loss of protein synthesis. Over $90 \%$ of mitochondrial proteins arise on cytoplasmic ribosomes (Beattie, 1971) and even a transitory interruption of protein synthesis could jeopardize the mitochondrion. On the other hand, the rates at which amino acids are incorporated in the protected animals exceeded those of controls at $26 \mathrm{hr}$ (Table 3), perhaps reflecting increased repair activity. In this interpretation, the preservation of protein synthesis by D-CAPS does not prevent the mitochondrial lesions, but assures that the cell can repair the incipient damage at a rate equal to its production. This would assume that the processes that lead to mitochondrial damage during $\mathrm{CCl}_{4}$ intoxication are not the same as those that lead to disruption of protein synthesis, which would be sensitive to interdiction by D-CAPS.

Lastly, observations from longstanding clinical use of D-CAPS predict that few side effects of the drug would be expected at the single, moderate dose $(50 \mathrm{mg} / \mathrm{kg})$ that was an effective antagonist to $\mathrm{CCl}_{4}$ in this study, indicating a real potential for therapeutic application in cases of acute intoxication from $\mathrm{CCl}_{4}$.

\section{ACKNOWLEDGMENT}

The technical assistance of Richard Hoyner is gratefully recognized and appreciated by the. authors. 


\section{REFERENCES}

Beattie, D. S. (1971). The synthesis of mitochondrial protein. Sub-Cell. Biochem. 1, 1-23. BRABEC, M. J., AND BERNSTEIN, I. A. (1975). Modulation of carbon tetrachloride-induced liver damage by chloramphenicol. Fed. Proc. Fed. Amer. Soc. Exp. Biol. 34, 664.

Brabec, M. J., Gray, R. H., AND Bernstern, I. A. (1974). Restoration of hepatic milochondria during recovery from carbon tetrachloride intoxication. Biochem. Pharmacol. 23, 32273238.

Cignoli, E. V., AND Castro, J. A. (1971). Effects of inhibitors of drug metabolizing enzymes on $\mathrm{CCl}_{4}$ hepatotoxicity. Toxicol. Appl. Pharmacol. 18, 625-637.

Contreras, A., Barbocid, M, AND VAzQUEZ, D. (1974). Binding to ribosomes and mode of action of CAP analogues. Biochem. Biophys. Acta 349, 376-388.

Dambrauskas, T., ANd CoRnish, H. $\mathrm{H}$. (1970). Effect of pretreatment of rats with $\mathrm{CCl}_{4}$ on tolerance development. Toxicol. Appl. Pharmacol. 17, 83-97.

DEVRIES, H., AND KROON, A. M. (1970). On the effect of chloramphenicol and oxytetracycline on the biogenesis of mammalian mitochondria. Biochem. Biophys. Acta 204, 531-541.

Dianzani, M. V., and UGazio, G. (1973). Lipoperoxidation after $\mathrm{CCl}_{4}$ poisoning in rats previously treated with antioxidants. Chem. Biol. Interac. 6, 67-69.

Dixon, R. L., AND FouTs, J. R. (1962). Inhibition of microsomal drug and metabolic pathways by chloramphenicol. Biochem. Pharmacol. 11, 715-720.

EstABROOK, R. W. (1967). Mitochondrial respiratory control and the polarographic measurement of ADP:0 ratios. In Methods in Enzymology (R. W. Estabrook and M. E. Pullman, Eds.), Vol. 10, pp. 41-47. Academic Press, New York.

Fettes, I. M., Haldar, D., and Freeman, K. B. (1972). Effect of chloramphenicol on enzyme synthesis and growth of mammalian cells. Canad. J. Biochem. 50, 200-209.

GLENDE, E. A. (1972). On the mechanism of $\mathrm{CCl}_{4}$ toxicity-coincidence of loss of drug metabolizing activity with peroxidation of microsomal lipid. Biochem. Pharmacol. 21, 1697-1702.

Grogan, D. E., Lane, M., Smith, F. E., Bresnick, E., and Stone, K. (1972). Interaction of flavins and chloramphenicol with microsomal enzyme systems. Biochem. Pharmacol. 21, 3131-3144.

HuYEN, H. I., AND BANASChaK, H. (1973). Schutzwirkung von Chloramphenikol gegenüber Tetrachlorkohlen-stoffin-toxikation bei der Ratze. Acta Biol. Med. Germ. 31, K1-K6.

JACOBS, E. E., JACOB, M., SANADI, D. R., AND BRADLEY, L. B. (1956). Uncoupling of oxidative phosphorylation by cadmium ion. J. Biol. Chem. 223, 147-156.

Lieberman, M. W., Verbin, R. S., Landay, M., Liang, H., Farber, E., Lee, T. N., and Starr, R. (1970). A probable role of protein synthesis in intestinal epithelial cell damage induced in vivo by cytosine arabinoside, nitrogen mustard or X-irradiation. Cancer Res. 30, 942-951.

MANS, R. J., AND Novelli, G. D. (1961). Measurement of the incorporation of radioactive amino acids into proteins by a filter paper dish method. Arch. Biochem. Biophys. 94, 48-53.

Marchand, C., McLean, S., PlaA, G. L., and Traiger, G. (1971). Protection by 2-diethylaminocthyl-2,2-diphenylvalerate hydrochloride against carbon tetrachloride hepatotoxicity. A possible mechanism of action. Biochem. Pharmacol. 20, 869-875.

Recknagel, R. O., Glende, E. A., Ugazio, G., Koch, R. R., and Srinivasan, S. (1974). New perspectives in the study of experimental carbon tetrachloride liver injury. In lnternational Symposium on Hepatotoxicity (M. Eliakim, J. Eshchos, and H. J. Zimmerman, Eds.), pp. 7-17. Academic Press, New York.

REYNOLDS, E. S. (1972). Comparison of early injury to liver endoplasmic reticulum by halomethanes, hexochloroethane, benzene, toluene, bromobenzene, ethionine, thioacetamide and dimethylnitrosamine. Biochem. Pharmacol. 21, 2555-2561.

Reynolds, E. S., ANd Moslen, M. T. (1974). Chemical modulation of early $\mathrm{CCl}_{4}$ liver injury. Toxicol. Appl. Pharmacol. 29, 377-388.

ReYNOLdS, E. S., AND ReE, H. J. (1971). Liver parenchymal cell injury. VII. Membrane denaturation following $\mathrm{CCl}_{4}$. Lab. Invest. 25, 269-278.

Reynolds, E. S., Thiers, R. E., ANd Vallee, B. L. (1962). Mitochondrial function and metal content in carbon tetrachloride poisoning. J. Biol. Chem. 237, 3546-3551. 
SCHEFLER, W. C. (1969). Statistics for the Biological Scientist, p. 68. Addison-Wesley Publishing Co., Reading, Massachusetts.

Simpson, M. V., Fournier, M. J., AND Skinner, D. M. (1967). Measurement of protein synthesis in mitochondria. In Methods of Enzymology (R. W. Estabrook and M. E. Pullman, Eds.), Vol. 10, pp. 755-762. Academic Press, New York.

SLATER, T. F., AND SAWYER, B. C. (1969). The effects of carbon tetrachloride on rat liver microsomes during the first hour of poisoning in vivo, and the modifying actions of promethazine. Biochem. J. 111, 317-324.

Smúckifr, F. A., Iseri, O. A., AND Benditr, E. P. (1962). Studies on carbon tetrachloride intoxication-The effect of $\mathrm{CCl}_{4}$ on incorporation of labeled amino acids into plasma proteins. J. Exp. Med. 116, 55-71. 